\title{
The use of a redox indicator to determine corrosiveness of wastewater towards metal structures
}

\author{
Denis Butko ${ }^{1}$, Elena Vilson ${ }^{1}$, and Elena Yakovleva ${ }^{1, *}$ \\ ${ }^{1}$ Don State Technical University, pl. Gagarina, 1, Rostov-on-Don, 344010, Russia
}

\begin{abstract}
Corrosion damages of metal structures of wastewater treatment facilities affect the work process parameters and operation safety. The analysis of the factors causing corrosion of metal elements and the assessment of corrosion resistance of the steel grades St08ps, St3sp and St5sp during the treatment stages, including the chlorine treatment, were conducted based on the data obtained from the Rostov-on-Don aeration plant. The article search techniques to determine the corrosiveness of water towards the metal structures. It is established that in this case it is advantageous to use redox indicator systems ( $\mathrm{rH} 2)$, which is calculated on the basis of field measurements of redox potential (ORP) of water. Based on the conducted studies, the correlation dependence for determining the corrosion rate of the steel grades St08ps and St5sp was suggested and statistically assessed for the aeration plant structures.
\end{abstract}

\section{Introduction}

Nowadays corrosion damages of metal structures are a significant economic problem for production companies in the wastewater treatment. The treatment facilities in Rostovon-Don are not an exception, as many main and additional construction structures are made of metal. Treatment facilities contain the following elements: grids, detritors, preliminary setting tanks with the preparation area, aero tanks with the nitrification area, secondary settling tanks, bioreactors for advanced treatment with brush filtering.

A review of the literature allowed identifying the most significant factors that determine the speed and depth of corrosion products of steel in the wastewater treatment process.

Contact of metal with wastewater triggers the electrochemical corrosion process leading to the formation of a solid layer of iron hydroxide on the metal surface, the corrosion rate decreases and gradually the process stops $[1,2]$. However, if the system contains corrosive depolarizers, the metal solution process continues [3].

Wastewaters supplied to the treatment facilities and being purified are multi-component systems, where various chemical and biochemical processes occur. Source substances and products of these reactions may demonstrate characteristics of depolarizers.

The next step will be to consider the most important depolarizers in reference to the wastewater/metal structures system, including pipelines:

\footnotetext{
* Corresponding author: ananas199021@yandex.ru
} 
- Oxygen. The main feature of the oxygen-type corrosion is a formation of pits on the metal surface, i. e. there is a pronounced local character of corrosion $[4,5]$. The corrosion products, iron (II and III) hydroxides, have a larger volume than iron, which they are formed of. Therefore, hillocks are often formed over pits with local corrosion. They are a sign of metal pit corrosion. Oxygen affects the corrosion intensity dually. Depending on its concentration in water and the presence of some other factors, it may stimulate corrosion or, on the contrary, suppress it (i. e. oxygen can be either a depolarizer or a polarizer)[6]. Iron is soluble in the water solution containing no oxygen with the formation of iron (II) hydroxide:

$$
\mathrm{Fe}+2 \mathrm{H}_{2} \mathrm{O}=\mathrm{Fe}(\mathrm{OH})_{2}+\mathrm{H}_{2},
$$

In the presence of oxygen, iron (III) hydroxide is formed based on the chemical equation:

$$
4 \mathrm{Fe}(\mathrm{OH})_{2}+\mathrm{O}_{2}+2 \mathrm{H}_{2} \mathrm{O}=4 \mathrm{Fe}(\mathrm{OH})_{3},
$$

In the result of this process, the formed protective film is not solid enough, and the formation of caverns becomes possible. Thus, oxygen acts as the anode depolarizer in this case. Cathodic depolarization by oxygen is related to oxygen acting as the acceptor of the electrons of the anode:

$$
4 \mathrm{E}+\mathrm{O}_{2}+2 \mathrm{H}_{2} \mathrm{O}=4 \mathrm{OH}^{-}
$$

The rate of the corrosion process with cathodic oxygen depolarization depends on the supply of oxygen consumed during the reaction. Oxygen can also act as the anode polarizer $[7,8]$. In sewage treatment facilities (STF), oxygenation occurs in the preaerator. Consequently, oxygen is also present in the preliminary setting tank, although its concentrations are low. Oxygen concentrations are consistently high (excluding a summer period when oxygen solubility drops) in the aero tank, while slightly lesser concentrations are observed in the preaerator and the secondary settling tank.

- Temperature. Temperature has a dual effect on the corrosion rate. On the one hand, the higher the temperature, the stronger the diffusion of dissolved oxygen to the metal surface, and the larger the corrosion effect. However, when temperature rises, the concentration of the dissolved oxygen decreases, thus reducing the effect of oxygen depolarization. Having analysed the literature data[9,10], we can state that a decrease in the corrosion rate occurs when the system's temperature is higher than $60^{\circ} \mathrm{C}$ that is not typical for the biological water treatment systems in the STFs.

- PH. The pH value depends on the concentration of hydrogen ions that may act as electron acceptors and enhance metal corrosion with hydrogen depolarization:

$$
2 \mathrm{E}+2 \mathrm{H}^{+}=\mathrm{H}_{2}
$$

According to the modern data, the processes of oxygen and hydrogen depolarization occur simultaneously, the former being characterized with oxygen ionization on the cathode portions, while the latter with hydrogen ions discharge. Consequently, we can conclude that the $\mathrm{pH}$ value in the range typical for municipal wastewater (the $\mathrm{pH}$ range of 6 to 9) does not suppress the corrosion process, and a $\mathrm{pH}$ below 7 even enhances it $[7,8]$.

- Chlorides. Chlorine ions are typical corrosion stimulating agents, as they weaken protective properties of oxide films. The mechanism of their destructive effect is based on the fact that chlorine ions can be absorbed by oxide films on the metal surface and can push out oxygen ions. In the result of such replacement of oxygen ions with chlorine ions, water- 
soluble ferriferous chloride is formed in the absorption points leading to the increase in the area of the anode portions [11-13].

- Sulphates. Sulphate ions can destroy an oxide film and induce the corrosion process. Data of the studies conducted by B. L. Reizin et al. showed that sulphate ions depending on their concentrations impact significantly corrosion processes in oversaturated aqueous solutions of calcium carbonate. Thus, in the $80 \mathrm{~s}$ of the 20th century employees of the Research and Development Institution Public Services Academy (RDI PSA) found that an increase in the sulphate ions concentration up to $100 \mathrm{mg} / \mathrm{dm}^{3}$ dramatically increases the system's corrosive properties [14]. The concentration of sulphate ions in wastewater of the Rostov-on-Don sewage treatment facilities in average comprises approx. $250 \mathrm{mg} / \mathrm{dm}^{3}$ suggesting a significant influence of this factor on the pipelines' corrosion rate.

- Reduced sulphur compounds (hydrogen sulphide and hydrosulphides)

If hydrogen sulphide and hydrosulphides are present in water, iron corrosion is significantly intensified $[7,15,16]$. The product of iron corrosion in water containing hydrogen sulphide is ferric sulphide $\mathrm{FeS}$ that does not form any solid protective film on metal and does not protect metal from future corrosion.

- Carbon dioxide.The presence of carbon dioxide and dissolved oxygen in water induces carbon corrosion that occurs simultaneously with oxygen and hydrogen depolarization (as the presence of carbon dioxide decreases the $\mathrm{pH}$ ). A significant amount of free carbon dioxide in water hinders the formation of solid protective films on metal. Iron oxide deposits are loose and can be easily washed away with a water flow [17]. If there is a deficit of dissolved oxygen in water, soluble iron oxide bicarbonate is formed:

$$
\mathrm{Fe}(\mathrm{OH})_{2}+2 \mathrm{CO}_{2}=\mathrm{Fe}\left(\mathrm{HCO}_{3}\right)_{2},
$$

If water contains enough oxygen and its $\mathrm{pH}$ is above 7, hydrolysis and iron oxide oxidation occur with the formation of the iron hydroxide suspension:

$$
4 \mathrm{Fe}\left(\mathrm{HCO}_{3}\right)_{2}+\mathrm{O}_{2}+2 \mathrm{H}_{2} \mathrm{O}=4 \mathrm{Fe}(\mathrm{OH})_{3}+8 \mathrm{CO}_{2},
$$

This reaction produces carbon dioxide that can dissolve ferrous hydroxide again.

With oxygen depolarization around the cathode, local sites are formed with an increased concentration of hydroxide ions. They react with calcium cations normally present in water shifting the carbon dioxide balance towards the carbonate formation.

$$
\mathrm{HCO}_{3}^{-}+\mathrm{OH}^{-} \rightarrow \mathrm{CO}_{3}^{2-}+\mathrm{H}_{2} \mathrm{O}
$$

This reaction produces calcium carbonate with low solubility that immediately deposits on the cathode portions of the corrosion cells. Deposits of calcium carbonate on the cathode portions inhibit corrosion.

With free carbon dioxide present in water in the amount exceeding an equilibrium concentration (aggressive carbon dioxide), the formation of calcium carbonate deposits is constrained creating conditions for corrosion intensification [18]. During wastewater treatment, in the aero tank there are conditions of the increased concentration of $\mathrm{CO}_{2}$, which is a product of metabolism of microorganisms [11].

- Microorganisms. Microbiological corrosion can manifest itself in different ways: with the immediate influence of products of microorganisms metabolism; with the formation of organic products that can act as depolarizers and catalysts of corrosion reactions; with the reactions being a separate part of the bacteria metabolic cycle [19-21].

According to the data obtained in the studies of D. K. Zabolotny Institute of MicrobiologyandVirology [22], there are two ways of inducing corrosion by microorganisms: - the formation of aggressive environments; - their immediate involvement into one or more electrochemical reactions on the corroded surface. For 
example, Ferrobacteria living on metal surfaces form slime masses with a high mechanical strength that cannot be washed away with water. Production of ferric iron hydroxide is accompanied with $\mathrm{pH}$ lowering to 5-6, i. e. the formation of an aggressive environment. Main initiators of corrosion in anaerobic conditions are Desulfovibrio, obligate anaerobes. Thionic bacteria oxidize sulphur into sulphuric acid, some thionic bacteria can oxidize ferrous iron into ferric iron that accepts electrons from the metal surface and acts as the cathode depolarizer.

- Rate of water flow on the metal surface. Entry and continuous movement of new water portions wash away a part of products produced in the reaction of iron and water creating favourable conditions for the corrosion processes [23, 24].

- Fouling on the surface of pipelines and structures. Accumulation of deposits on the surface due to the formation of stagnant zones leads to a lesser access of oxygen to these areas. Consequently, metal under the deposits acts as the anode, with ferric iron on the cathode portions in the form of iron oxide deposits or various types of sludge being a depolarizer. Inclusions of oxides or slags into steel significantly reduce its corrosion resistance [11].

The specific nature of the wastewater biological treatment method lies in the fact that at every stage of treatment certain conditions are created in water and the dominant effect of depolarizers of the corrosion processes changes. To assess the intensity of their effect we conducted the field studies. To assess the status of metal structures in the construction of wastewater aeration station of Rostov-on-don was originally produced by visual inspection, which allowed us to determine the following:

- Grids. All ferrous metal structures are protected from corrosion with a zink coating and coated with enamel and varnish, yet sites of corrosion damages were detected in the metal structures: rakes, all fixtures and inserts;

- Detritors. In the detritors, corrosion damages were found in a waterjet pump, a scraper system, cables, and a gate distribution channel. Bolted connections and inserts are elements most affected by corrosion.

- Preaerator. The main corrosion site in the preaerator is a lock valve.

- Preliminary setting tank. All metal structures are protected from corrosion, but the uniformity of the metal coatings was reduced with time alongside with progressive corrosion processes;

- Aerotank. The environment in the aerotank is aggressive enough for metal, as evidenced by the data of works [25-28]. The following structures are made of stainless steel: a clarified wastewater tray, gates, downcomers, a return activated sludge tray, bafflers. Corrosion sites are not visible in these elements. Many embedded and fitting elementsare made of galvanised steel susceptible to corrosion.

- Secondary settling tanks. Corrosion processes are still present in frames of thin-layer modules' cassettes and embedded details. Zinc-coated fixtures with a $30 \mu \mathrm{m}$ thick chrome plating connecting the serrated overflow to the collecting tray are destroyed with corrosion processes.

- Bioreactors. Bioreactors contain cassettes with brushes, their frame is made of stainless steel, and the brushes base is made of steel wire subject to corrosion and destruction that subsequently leads to brush filtering failures.

Metal structures and details used in the facilities and affected by corrosion are made of the steel grade St3sp with the following chemical composition (\%): $F e \sim 97 ; C-0.14-0.22$; $\mathrm{Si}-0.15-0.3 ; \mathrm{Mn}-0.4-0.65 ; \mathrm{Ni}$ up to $0.3 ; \mathrm{S}$ up to 0.05 ; P up to 0.04 ; up to $0.3 ; \mathrm{Cu}$ up to $0.3 ; \mathrm{As}$ up to 0.08 . The alloying additives to increase the corrosion resistance $\mathrm{Cr}, \mathrm{Ni}$ and $\mathrm{Cu}$ are used in very small quantities insufficient to increase the corrosion resistance of steel (e. g. chromium is mostly used to make steel more corrosion resistant provided that its 
content is $12-20 \%$. It forms a thin oxide film $\left(\mathrm{Cr}_{2} \mathrm{O}_{3}\right)$ on the alloy surface preventing metal from contacting with the environment that also raises the electrochemical potential of steel).

The objective of this paper is to determine the effective way of assessing the corrosion processes rate for metal depending on several factors changing in the course of wastewater treatment to substantiate the use of stainless steel structures.

A review of the literature [1-28] has shown that there is no Express analysis of determining the corrosivity of wastewater during purification in buildings. The study aimed at identifying reliable rapid analysis of the corrosivity of the environment to justify the use of metal of stainless steel, are relevant.

The aim of the research is the definition of reliable rapid analysis evaluation of corrosion rate of steel in wastewater.

To achieve this goal required the following tasks.

1. Determination of corrosion rate of steel depending on the factors that determine the quality of wastewater during purification in buildings.

2. Evaluation of possibility of application of various methods of predicting corrosion rates of metallic elements.

3. The possibility of using ORP environment for the evaluation of corrosion rate of steel in wastewater.

4. Determination of the correlation between indicators of ORP and corrosion rate of steel in wastewater.

\section{Methods}

According to [29] measurement and control of speed of corrosion in water systems in Europe are most often produced by the method of calibrated samples. Used specimens of known weight (after cleaning) and known surface area is cut out of the tested metal. The corrosion rate measured in $\mathrm{mm} /$ year. Typically, the samples are installed in the test environment for 1-3 months. After the test, the samples are cleaned and weighed.

Steel samples made of the steel grade St5sp (Russian state standartGOST380-2005) and St08ps (Russian state standartGOST 1050-88) were chosen for the studies. The chemical composition of steel St08ps in \%: Fe 98; C- 0.05-0.11; Si- 0.05-0.17; Mn - 0.35-0.65; Ni up to $0.25 ; S$ up to $0.04 ; P$ up to $0.035 ; C r$ up to $0.1 ; C u$ up to $0.25 ; A s$ up to 0.08 . The specification of steel St08ps (Russian state standartGOST 1050-88): high quality structural carbon steel for production of parts with high plasticity requirements: washers, fittings, gaskets and other minor parts used in the temperature range from -40 to $450{ }^{\circ} \mathrm{C}$, with the density of $7,846 \mathrm{~kg} / \mathrm{m}^{3}$. The chemical composition of steel St5sp in \%: Fe 98; C- $0.28-$ 0.37 ; $\mathrm{Si}-0.15-0.3 ; \mathrm{Mn}-0.5-0.8 ; \mathrm{S}$ up to 0.05 ; P up to 0.04 . The specification of steel St5sp: structural carbon steel of commercial quality for production of parts of riveted structures, bolts, screws, handles, plugs, feed rods, pins, pipe plates, flanges and other parts used in the temperature range of $0-425^{\circ} \mathrm{C}$, with the density of $7,850 \mathrm{~kg} / \mathrm{m}^{3}$.

The samples were placed into the detritors, preaerator, preliminary setting tank, aerotank, secondary settling tanks, bioreactor, and the contact tank. The samples and the study itself were prepared in compliance with the methods stated in [22]: the samples for one test run were cut from one metal sheet. Prior to dipping into the studied media, the samples were polished with sandpaper, degreased with petrol, flushed with acetone and ester for degreasing the surfaces. They were left in the exiccator for 30 mins and then weighted. Afterwards, the samples were placed into the studied media and left there for 30 days. At the end of the study period the samples were pulled out. Corrosion products were removed by placing the samples into pickling solutions. After pickling, the samples were rinsed with running water for $30 \mathrm{mins}$, and then with petrol, acetone and ester, in succession. Afterwards, they were dried in the exiccator for $30 \mathrm{mins}$ and weighted. The 
arithmetic mean of three parallel measurements is considered to be the result of the test. The study data are shown in Table 1, where the following notations are used: $S$ - surface area of the sample; $\Delta P$ - difference in the sample weight before and after tests; $\mathrm{K}-$ corrosion rate of the sample.

The corrosion rate of metal materials in various media is determined by the reduction of the sample's mass (after removal of corrosion products) on a unit of surface in a unit of time and is expressed in grams per sq. meter per hour. The corrosion depth index is expressed in linear units per unit of time:

$$
\mathrm{P}=\frac{8.76 \mathrm{~K}}{\gamma}
$$

where $\mathrm{P}$ - corrosion depth index, $\mathrm{mm} / \mathrm{year} ; \mathrm{K}$ - corrosion rate, $\mathrm{g} /\left(\mathrm{m}^{2} \mathrm{~h}\right) ; \gamma$ - metal density, $\mathrm{g} / \mathrm{cm}^{3}$.

Table 1. The studies of the corrosion rate in the wastewater treatment facilities with the 30day exposure period (the Table contains the arithmetic means of three parallel measurements for ${ }_{\Delta} \mathrm{P}, \mathrm{g}$ and $\mathrm{K}, \mathrm{mg} \mathrm{Fe} / \mathrm{cm}^{2}$ per day)

\begin{tabular}{|c|c|c|c|c|c|c|}
\hline \multirow{2}{*}{ Facilities } & \multicolumn{3}{|c|}{ Steel Grade St5sp Sample } & \multicolumn{3}{c|}{ Steel Grade St08ps Sample } \\
\cline { 2 - 7 } & $\mathrm{S}, \mathrm{cm}^{2}$ & ${ }_{\Delta} \mathrm{P}, \mathrm{g}$ & $\begin{array}{c}\mathrm{K}, \mathrm{mg} \\
\mathrm{Fe} / \mathrm{cm}^{2} \text { per } \\
\text { day }\end{array}$ & $\mathrm{S}, \mathrm{cm}^{2}$ & ${ }_{\Delta} \mathrm{P}, \mathrm{g}$ & $\begin{array}{c}\mathrm{K}, \mathrm{mg} \\
\mathrm{Fe} / \mathrm{cm}^{2} \text { per } \\
\text { day }\end{array}$ \\
\hline Detritors & 13.840 & 0.075 & 0.308 & 29.320 & 0.493 & 0.093 \\
\hline Preaerator & 13.840 & 0.216 & 1.115 & 29.320 & 0.964 & 0.183 \\
\hline $\begin{array}{c}\text { Preliminary } \\
\text { setting tank }\end{array}$ & 13.840 & 0.179 & 0.920 & 29.320 & 0.490 & 0.093 \\
\hline Aerotank & 13.840 & 0.100 & 0.557 & 29.320 & 0.603 & 0.114 \\
\hline $\begin{array}{c}\text { Secondary } \\
\text { settlingtank }\end{array}$ & 13.840 & 0.098 & 0.500 & 29.320 & 1.089 & 0.206 \\
\hline $\begin{array}{c}\text { Bioreactor } \\
\text { Contacttank } \\
\text { (chlorine } \\
\text { treatment) }\end{array}$ & 13.840 & 0.139 & 0.710 & 29.320 & 1.006 & 0.191 \\
\hline \multicolumn{2}{c}{13.840} & 0.203 & 1.050 & 29.320 & 2.294 & 0.435 \\
\hline
\end{tabular}

According to Russian state standartGOST 5272-68 Corrosion of Metals. Terms (Amendments No 1,2), the corrosion resistance of metal materials is assessed using the ten-point scale. Rating points are given in Table 2.

Table 2. Rating Points of Corrosion Resistance of Metals (according to Russian Standart GOST 5272-68)

\begin{tabular}{|c|c|c|c|c|c|}
\hline Resistance Group & $\mathrm{P}, \mathrm{mm} /$ year & Point & Resistance Group & $\mathrm{P}, \mathrm{mm} /$ year & Point \\
\hline I - fully resistant & $<0.001$ & 1 & $\begin{array}{l}\text { IV - decreased } \\
\text { resistance }\end{array}$ & $\begin{array}{l}0.10-0.50 \\
0.50-1.00\end{array}$ & $\begin{array}{l}6 \\
7\end{array}$ \\
\hline II - highly resistant & $\begin{array}{c}0.001- \\
0.005\end{array}$ & 2 & $\mathrm{~V}$ - low resistance & $\begin{array}{c}1.00-5.00 \\
5.00-10.00\end{array}$ & $\begin{array}{l}8 \\
9\end{array}$ \\
\hline III - resistant & $\begin{array}{c}0.005-0.01 \\
0.01-0.10 \\
0.05-0.10\end{array}$ & $\begin{array}{l}3 \\
4 \\
5\end{array}$ & VI - no resistance & $>10.00$ & 10 \\
\hline
\end{tabular}

Table 3 shows the rating points and the groups of resistance for the samples of the studied steel grades depending on the conditions of the test media. 
Table 3.Rating Points and Resistance Groups of the Samples

\begin{tabular}{|c|c|c|c|c|c|c|}
\hline \multirow[b]{2}{*}{ Facilities } & \multicolumn{3}{|c|}{ Steel Grade St5sp Sample } & \multicolumn{3}{|c|}{ Steel Grade St08ps Sample } \\
\hline & $\begin{array}{c}\mathrm{K} \\
\mathrm{g} / \mathrm{m}^{2} \\
\mathrm{~h}\end{array}$ & $\begin{array}{c}\mathrm{P}, \\
\mathrm{mm} / \text { yea } \\
\mathrm{r}\end{array}$ & $\begin{array}{c}\text { Group of } \\
\text { Resistance/poin } \\
\mathrm{t}\end{array}$ & $\begin{array}{c}\mathrm{K} \\
\mathrm{g} / \mathrm{m}^{2} \\
\mathrm{~h}\end{array}$ & $\begin{array}{c}\mathrm{P}, \\
\mathrm{mm} / \text { yea } \\
\mathrm{r}\end{array}$ & $\begin{array}{c}\text { Group of } \\
\text { Resistance/po } \\
\text { int }\end{array}$ \\
\hline Detritors & 0.128 & 0.1432 & $\begin{array}{l}\text { IV - decreased } \\
\text { resistance/ } 6\end{array}$ & 0.0388 & 0.0432 & III - resistant/ 4 \\
\hline Preaerator & 0.4646 & 0.5184 & $\begin{array}{c}\mathrm{V}-\text { low } \\
\text { resistance/ } 7\end{array}$ & 0.0763 & 0.08 & III - resistant/ 5 \\
\hline $\begin{array}{l}\text { Preliminar } \\
\text { y setting } \\
\text { tank }\end{array}$ & 0.3833 & 0.4278 & $\begin{array}{l}\text { IV - decreased } \\
\text { resistance/ } 6\end{array}$ & 0.0388 & 0.0432 & III - resistant/ 4 \\
\hline Aerotank & 0.2321 & 0.2590 & $\begin{array}{l}\text { IV - decreased } \\
\text { resistance/ } 6\end{array}$ & 0.0475 & 0.0530 & III - resistant/ 5 \\
\hline $\begin{array}{l}\text { Secondary } \\
\text { settling } \\
\text { tank } \\
\end{array}$ & 0.2083 & 0.2325 & $\begin{array}{l}\text { IV - decreased } \\
\text { resistance/ } 6\end{array}$ & 0.0858 & 0.0958 & III - resistant/ 5 \\
\hline Bioreactor & 0.2958 & 0.3300 & $\begin{array}{l}\text { IV - decreased } \\
\text { resistance/ } 6\end{array}$ & $\begin{array}{c}0.0795 \\
8\end{array}$ & 0.0888 & III - resistant/ 5 \\
\hline $\begin{array}{c}\text { Contact } \\
\text { tank } \\
\text { (chlorine } \\
\text { treatment) }\end{array}$ & 0.4375 & 0.4883 & $\begin{array}{l}\text { IV - decreased } \\
\text { resistance/ } 6\end{array}$ & 0.18 & 0.2023 & $\begin{array}{l}\text { IV - decreased } \\
\text { resistance/ } 6\end{array}$ \\
\hline
\end{tabular}

The analysis of the study's results shows that corrosiveness of wastewater is rather high in the process of treatment. As the conducted studies with the samples of metals (alloys) are rather time-consuming, further studies were aimed at searching for representative parameters typical for the medium corrosiveness that could be determined with measurement instruments and calculations.

In the water supply industry it is commonly assumed that water aggressiveness calculated using its stability index is indicative of corrosiveness.

Water stability is determined using the calcium carbonate saturation index I.

$$
\mathrm{I}=P H_{0}-P H_{s},
$$

where $P H_{O}$ - water $\mathrm{pH}$ value measured with a $\mathrm{PH}$ meter;

$\mathrm{PH}_{s}-\mathrm{pH}$ value in conditions of water saturation with calcium carbonate (Russian construction norms and rules SP 31.13330.2012, SNiP 2.04.02-84. Water Supply. External Networks and Facilities, 2015), based on the values of calcium content $\mathrm{C}_{\mathrm{CA}}$, total salt content $\mathrm{P}$, alkalinity $\mathrm{A}$ and water temperature $t$. The $\mathrm{pHs}$ value is calculated based on the water analysis data using the formula:

$$
P H_{s}=f_{1}(t)+f_{2}\left[C^{2+}\right]-f_{3}(A)+f_{4}(P),
$$

where $f_{l}(t), f_{2}\left[\mathrm{Ca}^{2+}\right], f_{3}(A)$ and $f_{4}(P)$ are functions of water temperature, its calcium content, alkalinity and total salt content in water, correspondingly; a nomogram is used to calculate values of these parameters.

The stability index is calculated on the basis of quality parameters of wastewater before and after treatment. The estimates of stability indices are given in Table 4.

According to the estimated data, it can be stated with a $95 \%$ probability that wastewater both before and after treatment has the stability index above zero (I $>0)$ proving 
its non-aggressiveness, and, consequently, non-corrosiveness of wastewater. However, in practice we observe corrosion of steel structures contacting with wastewater.

Table 4. Stability Indices (I) Values for Untreated and Treated Wastewater

\begin{tabular}{|c|c|c|c|c|c|c|}
\hline \multirow{2}{*}{ Months } & \multicolumn{3}{|c|}{ Untreated Wastewater } & \multicolumn{3}{c|}{ Wastewater after Treatment } \\
\cline { 2 - 7 } & $\mathrm{pH}$ & $\mathrm{pHs}$ & $\mathrm{I}$ & $\mathrm{pH}$ & $\mathrm{pHs}$ & $\mathrm{I}$ \\
\hline December & 7.77 & 7.15 & 0.55 & 7.84 & 7.25 & 0.59 \\
\hline January & 7.73 & 7.20 & 0.53 & 7.84 & 7.30 & 0.54 \\
\hline February & 7.67 & 7.20 & 0.47 & 7.8 & 7.35 & 0.45 \\
\hline March & 7.65 & 7.05 & 0.60 & 7.76 & 7.08 & 0.68 \\
\hline April & 7.29 & 7.15 & 0.14 & 7.85 & 7.18 & 0.67 \\
\hline May & 7.96 & 7.20 & 0.76 & 7.49 & 7.25 & 0.24 \\
\hline June & 7.73 & 7.10 & 0.63 & 7.78 & 7.20 & 0.58 \\
\hline July & 7.73 & 7.12 & 0.61 & 7.77 & 7.20 & 0.57 \\
\hline August & 7.65 & 7.05 & 0.60 & 7.74 & 7.23 & 0.51 \\
\hline September & 7.70 & 7.00 & 0.70 & 7.63 & 7.10 & 0.53 \\
\hline October & 7.70 & 7.00 & 0.70 & 7.71 & 7.20 & 0.51 \\
\hline November & 7.80 & 7.00 & 0.80 & 7.73 & 7.25 & 0.48 \\
\hline
\end{tabular}

The discrepancy may be caused by the fact that the stability index value $I$ cannot be used to assess wastewater aggressiveness as in the wastewater treatment the factors not considered in calculating the stability $I$ may have a dominant impact. These factors are main depolarizers of the corrosion processes during treatment and transportation of natural waters. For example, the film formed with $\mathrm{CACO}_{3}$ deposits is not strong and solid enough; consequently, it cannot prevent the local corrosion processes[14].

The specialists of the Research and Development Institution Public Services Academy (RDI PSA) n. a. K. D. Pamfilov suggested the methods for determining the water aggressiveness with the consideration of the sulphate ions content:

$$
T=\frac{U_{1}}{U_{2}^{0.5}},
$$

where $T$ is a criterial factor for calculating the aggressiveness $\mathrm{K}$ based on the corresponding nomograms (Pic. 1); $U_{I}$ is the concentration of sulphate ions in water, $\mathrm{mg}$ eq $/ \mathrm{dm}^{3} . U_{1}=S_{4}{ }^{2-} / 48 ; U_{2}$ is the water alkalinity, $\mathrm{mg}$-eq $/ \mathrm{dm}^{3}\left(\mathrm{~mol} / \mathrm{dm}^{3}\right)$.

Based on the recommendations of the RDI PSA n. a. K. D. Pamfilov, we performed calculations showing that wastewater is highly aggressive that is confirmed with the data of the pilot studies of the steel samples contacting with wastewater at various phases of its treatment. However, the analysis of the estimates and the experimental data shows that the corrosion rate of the samples is actually $40 \%$ larger than the estimated rate (Table 5). Consequently, the methods for determining the water aggressiveness with the consideration of solely the content of sulphate ions and hydrocarbonate ions also cannot adequately assess the extent of wastewater aggressiveness at these treatment stages.

The above factors affecting the wastewater aggressiveness are more or less manifested depending on the aerobicity extent and the $\mathrm{pH}$ value at the wastewater treatment stages. Both parameters are essential for the oxidation-reduction environment and should be taken into consideration while estimating the oxidation-reduction value of the system $\left(\mathrm{rH}_{2}\right) \cdot \mathrm{rH}_{2}$ is estimated based on the in-situ measurements of the oxidation-reduction potential (ORP). This value can be quickly and rather easily determined using the corresponding devices: a 
PH meter, a device for measuring the oxidation-reduction potential and an oxygen analyzer.Based on the readings of the latter, we can determine a normal oxygen potential on the diagram with the consideration of the $\mathrm{pH}$ value and then calculate the current ORP value with regard to temperature.

$$
r H_{2}=\left(\frac{E h}{0.029}\right)+P H
$$

Where $E h$ is an estimated or actually measured ORP value, V.

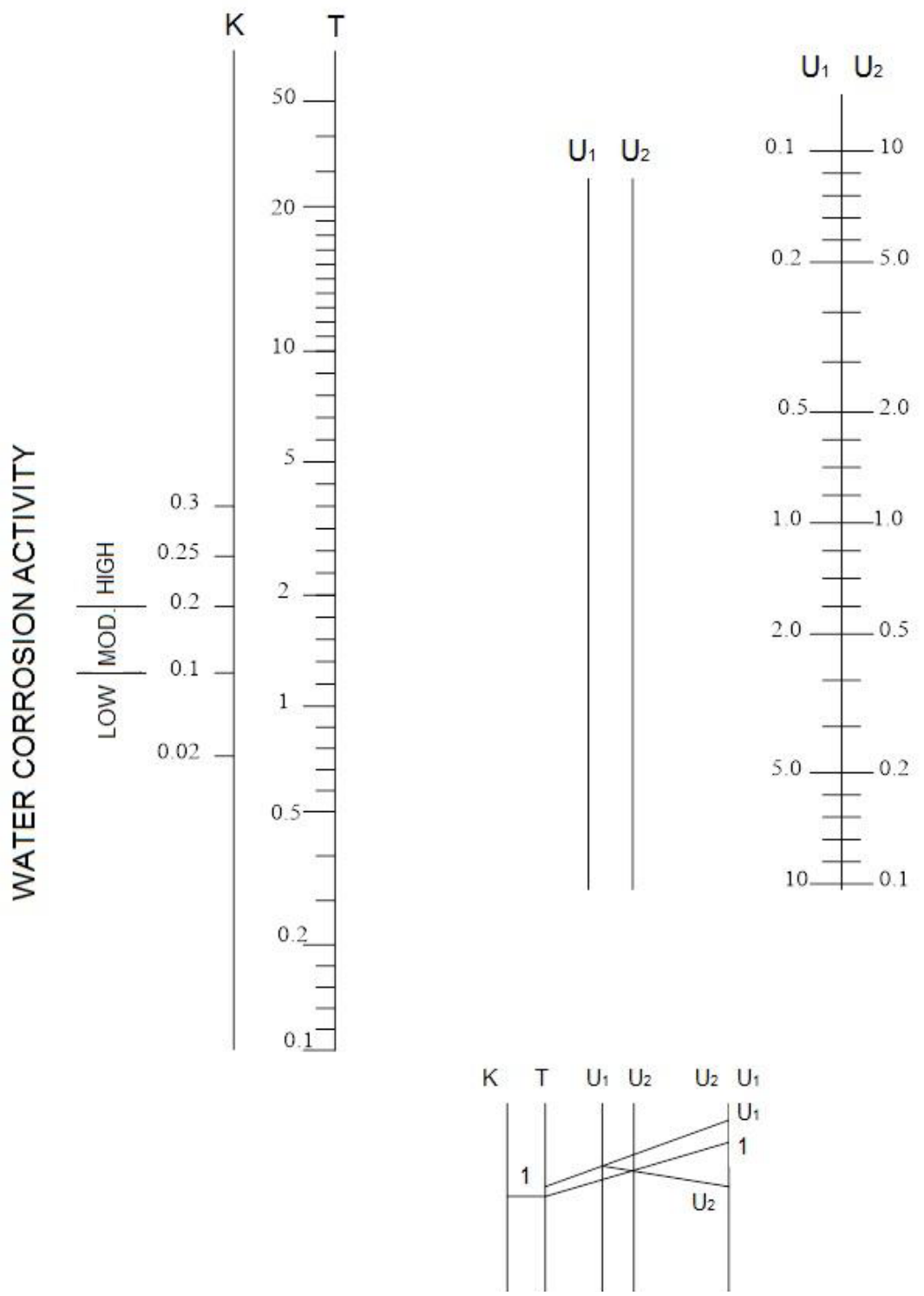

Fig. 1. Nomogram for determining the water aggressiveness depending on the sulphate ions concentration 
Table 5. Aggressiveness for steel grade St5sp based on the estimated and experimental data

\begin{tabular}{|c|c|c|c|c|c|c|c|}
\hline \multirow[b]{3}{*}{ Facility } & \multicolumn{6}{|c|}{ Aggressiveness Determination } & \multirow[b]{3}{*}{$r H_{2}$} \\
\hline & \multicolumn{3}{|c|}{ Estimated } & \multicolumn{3}{|c|}{ Experimental } & \\
\hline & $\begin{array}{c}U_{l}, \\
\mathrm{mg} \mathrm{eq} / \mathrm{dm}^{3}\end{array}$ & $\begin{array}{c}U_{2}, \\
\mathrm{mg} \mathrm{eq} / \mathrm{dm}^{3}\end{array}$ & $\begin{array}{c}\mathrm{K}, \\
\mathrm{mg} F e / \mathrm{cm}^{2} \\
\text { per day }\end{array}$ & $\begin{array}{l}S, \\
\mathrm{~cm}^{2}\end{array}$ & $\begin{array}{c}\Delta P, \\
\mathrm{~g}\end{array}$ & $\begin{array}{c}\mathrm{K}, \\
\mathrm{mg} \mathrm{Fe} / \mathrm{cm}^{2} \\
\text { per day }\end{array}$ & \\
\hline Detritors & 4.560 & 6.550 & 0.180 & 13.840 & 0.075 & 0.308 & - \\
\hline Preaerator & 4.560 & 6.050 & 0.190 & 13.840 & 0.216 & 1.115 & - \\
\hline $\begin{array}{l}\text { Preliminary } \\
\text { setting tank }\end{array}$ & 4.560 & 6.030 & 0.200 & 13.840 & 0.179 & 0.920 & - \\
\hline Aerotank & 3.990 & 4.150 & 0.240 & 13.840 & 0.100 & 0.557 & 20.03 \\
\hline $\begin{array}{c}\text { Secondary } \\
\text { settling tank }\end{array}$ & 3.990 & 4.000 & 0.260 & 13.840 & 0.098 & 0.500 & 19.2 \\
\hline Bioreactor & 3.990 & 4.400 & 0.250 & 13.840 & 0.139 & 0.710 & 21.68 \\
\hline Contact tank & 3.990 & 4.950 & 0.270 & 13.840 & 0.203 & 1.050 & 27.48 \\
\hline
\end{tabular}

The analysis of literature data shows that the impact of the ORP of the wastewater on the corrosion of metal elements of construction were not considered. There are only data on the influence of the electrode potential of the material on the rate of corrosion[30].

Further studies were designed to determine the correlation dependence between the corrosion rate $(\mathrm{K})$ and the oxidation-reduction value $\left(\mathrm{rH}_{2}\right)$.

The objective of the studies was to determine the form of the regression equation that shows the link between $\mathrm{K}$ and $\mathrm{rH}_{2}$ and based on the current $\mathrm{rH}_{2}$ value to determine the corrosion rate for ferrous metals. If the corrosion rate is not economically justifiable, the obtained results serve as a ground for replacement of the metal parts made of St3, St5sp, St08ps steel with the steel parts with a larger content of corrosion resistant alloying additives.

To determine the correlation dependence between the oxidation-reduction value and the corrosion rate in the biological treatment facilities we used the linear correlation coefficient $\left(r_{x y}\right)[31]$ :

$$
r_{x y}=\frac{\sum\left(x_{i}-x_{\text {mean }}\right) \cdot\left(y_{i}-y_{\text {mean }}\right)}{\left(\sum\left(x_{i}-x_{\text {mean }}\right)^{2} \cdot \sum\left(y_{i}-y_{\text {mean }}\right)^{2}\right)^{0.5}}
$$

where $x_{i}$ is a current $\mathrm{rH}_{2}$ value $x_{\text {mean }}$ is a mean $\mathrm{rH}_{2}$ value; $y$ is a current corrosion value, $\mathrm{mg} \mathrm{Fe} / \mathrm{cm}^{2}$ per day; $y_{\text {mean }}$ is a mean corrosion value, $\mathrm{mg} \mathrm{Fe} / \mathrm{cm}^{2}$ per day.

It is also noteworthy that under the current $\mathrm{rH}_{2}$ and $\mathrm{K}$ values the statistically mean values of three parallel measurements in each facility are given.

This fact shall be considered when determining the significance of the correlation coefficient.

The next stage was an attempt to obtain regression equations for separate treatment phases. This article shows the result of determining the linear correlation between the oxidation-reduction value and the corrosion rate for the biological treatment process (aerotank - secondary settling tank - bioreactor).

The data for calculating the coefficient of correlation between the corrosion rate of the St.5 steel sample and the oxidation-reduction value in the biological treatment facilities are shown in Table 6. 
Table 6. The data for calculating the correlation coefficient

\begin{tabular}{|c|c|c|c|c|c|c|c|}
\hline Facility & $\mathrm{X}\left(\mathrm{rH}_{2}\right)$ & $\mathrm{y}(\mathrm{K})$ & $\begin{array}{c}\mathrm{x}_{\mathrm{i}^{-}} \\
\mathrm{x}_{\text {mean }}\end{array}$ & $\mathrm{y}_{\mathrm{i}^{-}-\mathrm{y}_{\text {mean }}}$ & $\begin{array}{c}\left(\mathrm{x}_{\mathrm{i}}-\mathrm{x}_{\text {mean }}\right. \\
\left(\mathrm{y}_{\mathrm{i}}-\mathrm{y}_{\text {mean }}\right)\end{array}$ & $\left.\begin{array}{c}\left(\mathrm{x}_{\mathrm{i}^{-}}\right. \\
\mathrm{x}_{\text {mean }}\end{array}\right)^{2}$ & $\left(\mathrm{y}_{\mathrm{i}}-\mathrm{y}_{\text {mean }}\right)^{2}$ \\
\hline $\begin{array}{c}\text { Aerotank } \\
\begin{array}{c}\text { Secondary } \\
\text { settling } \\
\text { tank }\end{array}\end{array}$ & 20.03 & 0.557 & -0.27 & -0.032 & 0.0086 & 0.073 & 0.001 \\
\hline Bioreactor & 21.68 & 0.710 & 1.38 & 0.121 & 0.167 & 1.9 & 0.015 \\
\hline & $\begin{array}{c}\mathrm{x}_{\text {mean }}= \\
20.23\end{array}$ & $\begin{array}{c}\mathrm{y}_{\text {mean }} \\
=0.589\end{array}$ & & & $\begin{array}{c}\Sigma \\
=0.274\end{array}$ & $\begin{array}{c}\Sigma= \\
3.183\end{array}$ & $\Sigma=0.024$ \\
\hline
\end{tabular}

$$
r_{x y}=\frac{0.274}{(1.784 \cdot 0.155)}=0.99
$$

The empirical correlation coefficient like any other sample parameter acts as a measure of its population parameter and being a random variable is associated with the representation error of its population parameter $\mathrm{s}_{\mathrm{r}:}$ :

$$
s_{r}=\sqrt{\frac{1-r^{2}}{n-2}}
$$

The ratio of the correlation coefficient to its error is a testing criterion for the null hypothesis - the assumption that there are no correlation between the properties in the population. The null hypothesis is rejected at the accepted significance level $\alpha$, if the estimated value of the correlation criterion is less than the critical value $\left(\mathrm{t}_{\mathrm{T}}\right)$.

If the number of measurements is less than 30 (in our case 9: 3 facilities, 3 measurements in each facility), the estimated criterion of correlation $\left(\mathrm{r}_{\mathrm{xy}}{ }^{*}\right)$ is calculated using the formula:

$$
r_{x y}\left[1+\frac{1-r_{x y}^{2}}{2(n-3)}\right]
$$

In this case $r_{x y} *=0.99 \cdot\left[1+\frac{1-0.98}{2(9-3)}\right]=0.99$

Mathematical statistics shows that if a significant correlation between $\mathrm{x}$ and $\mathrm{y}$ is present $\left(\mathrm{r}_{\mathrm{xy}}\left(\mathrm{r}_{\mathrm{xy}}{ }^{*} \geq\right.\right.$ 0.5 ), a sampling distribution of a correlation coefficient for samples from a population having a normal distribution significantly deviates from a normal curve. Consequently, the sampling correlation coefficient is not an accurate estimate of the population parameter. In this case $\left(\mathrm{r}_{\mathrm{xy}}{ }^{*}\right)$ is replaced with the transformed variable $\mathrm{z}$ that is related to the empirical correlation coefficient in the equation:

$$
\mathrm{z}=0,5 \ln \frac{1+r}{1-r}=1.15129 \lg \frac{1+r}{1-r},
$$

In this case, $\mathrm{z}=2.3$. The test of validity of $\mathrm{z}$ is $\mathrm{t}_{\mathrm{z}}$ :

$t_{z}=\frac{z}{s_{z}}=z \sqrt{n-3}=2.3 \cdot 2.45=5.63$ 
To determine the correlation significance the calculated $t_{\mathrm{z}}$ test is compared to the table value $\mathrm{t}_{\mathrm{T}}$ determined using the Student's t-test table with regard to the significance level $\alpha$; with the accepted significance level $\alpha=0.05 \mathrm{t}_{\mathrm{T}}=1.96$. Since $5.63>1.96$, the null hypothesis about the absence of correlation is rejected. There is a correlation between the oxidation-reduction value and the corrosion rate.

\section{Results and Discussion}

The correlation dependence determines the type of the regression equation used to determine the corrosion rate of metal parts made of St5sp steel in the given range of changes of the oxidation-reduction value. The general regression equation has the following form:

$$
y_{i}-y_{\text {mean }}=r_{x y}\left(\frac{S_{y}}{S_{x}}\right)\left(x_{i}-x_{\text {mean }}\right),
$$

where $\mathrm{S}_{\mathrm{y}}$ and $\mathrm{S}_{\mathrm{x}}$ are the least square variance corresponding to $\mathrm{y}$ and $\mathrm{x}$.

$y_{i}=0.99\left(\frac{0.05}{0.728}\right)\left(x_{i}-20.23\right)+0.589$

Taking into account that $\mathrm{y}$ in this case is a corrosion rate $\mathrm{K}, \mathrm{mg} \mathrm{Fe} / \mathrm{cm}^{2}$ per day, and $\mathrm{x}$ is $\mathrm{rH}_{2}$, then the corrosion rate for St5sp steel in the biological treatment facilities under the aerobic conditions can be calculated using the equation:

$$
K=0.068 \mathrm{rH}_{2}-0.79
$$

The dependence was obtained during the studies conducted in the warm season (June). In the winter season (December), we obtained the data establishing the following regression equation for $\mathrm{St} 5 \mathrm{sp}$ steel:

$$
K=0.12 r H_{2}-1.55 \text {. }
$$

It was observed that in the winter period water aggressiveness increases that apparently contradicts to the literature data showing the increase in the corrosion rate with the rise of temperature. Apparently, in this case the temperature effect is less significant (the difference in wastewater temperatures in the warm and cold seasons is approx. $10^{\circ} \mathrm{C}$ ) than the dissolved oxygen factor (oxygen solubility significantly reduces with an insignificant increase in temperature). The equation for calculating the aggressiveness in a cold season was obtained using the St08ps steel:

$$
K=0.341 r H_{2}-6.158 .
$$

The following data were used for the calculations: $\mathrm{X}\left(\mathrm{rH}_{2}\right)$ comprised 20.53 in the aerotank; 20.440 in the secondary settling tank; 21.930 in the bioreactor. The corrosion rate $\mathrm{y}(\mathrm{K})$ was:in the aerotank 0.114 ; in the secondary settling tank0.206; in the bioreactor 0.191 . The given equations can be used for determining the corrosion rate in the biological treatment system. Subsequently, using the data in Table 2 it is possible to determine the corrosion resistance group of metal and to state if it should be replaced with alloy steel. The novelty of the findings is confirmed by the absence of such data in the literature [128].

\section{Conclusions}

1. In the process of sewage treatment in the construction conditions, causes serving the corrosion of metallic elements 
2. The article discusses various methods of measuring and predicting corrosion rates of metallic elements. We have found that the use of methods for assessing the aggressiveness of the water in terms of $\mathrm{pH}$ and the criterion factor for the calculation of the corrosion activity given the concentration of sulfate ions for evaluation of corrosiveness of wastewater is not advisable.

3. It was found that a reliable indicator of rate of corrosion of metal elements in municipal wastewater treatment plants is the oxidation-reduction index $\left(\mathrm{rH}_{2}\right)$.

4. Were obtained the equations for calculating the corrosion activity in cold and warm periods of the year on the basis of the found correlations of corrosion rate from the redox indicator.

\section{References}

1. S.S. Orlova, T.A. Pankova, Agrarnyy nauchnyy zhurnal, 10, 44-47 (2015)

2. S.S. Orlova, T.A. Pankova, A.V. Kochetkov, Gidrotekhnicheskoye stroitelstvo, 4, 30-36 (2016)

3. N. D. Tomashov, Theory of Corrosion and Corrosion-Resistant Structural Alloys (Metallurgiya, Moscow, 1993)

4. O.N. Bystrova, Vestnik kazanskogo tekhnologicheskogo universiteta, 19(4), 43-46 (2016)

5. O.N. Bystrova, Vestnik Kazanskogo tekhnologicheskogo universiteta, 17(20), 302-306 (2014)

6. A.Yu. Koryakin, I.M. Kolesnikov, M.Yu. Kilyanov, S.I. Kolesnikov, TERRITORIYa NEFTEGAZ, 3, 70-74 (2015)

7. Ye.V. Vilson, URL : http://naukovedenie.ru/PDF/49trgsu313.pdf (11.11.2016)

8. G.G. Vinokurtsev, V.V. Pervunin, V.A. Krupin, Protection from Corrosion of Underground Pipelines and Facilities (Rost. gos. stroit. un-t, Rostov-na-Donu, 2003)

9. S. Roychowdhury, V. Kain, S. Neogy, D. Srivastava, G.K. Dey, R.C. Prasad, Acta Materialia, 60( 2), 610-621 (2012)

10. V.N. Yesenin, L.I. Denisovich, Zhurnal prikladnoy khimii, 81(11) 1772. (2008)

11. A.A. Gerasimenko, Protection of Machines, Equipment and Facilities from Corrosion, Ageing and Biodeterioration, (Mashinostroyeniye, Moscow, 1987)

12. O.N. Bystrova, Vestnik Kazanskogo tekhnologicheskogo universiteta, 15(9), 243$245(2012)$

13. O.N. Bystrova, Vestnik Kazanskogo tekhnologicheskogo universiteta, 2, 98-103 (2011)

14. N. Vatin, N. Lavrov, G. Loginov, MATEC Web of Conferences, 73, (2016), DOI $10.1051 /$ matecconf $/ 20167301006$

15. H.V. Chumalo, Serviceability of $35 \mathrm{KHF}$ steel in hydrogen-sulfide media Materials Science, 46(3), 408-411 (2010)

16. N.I. Mursalov, Sh.Z. Dzhabrailzade, V.M. Abbasov, A.A. Guliyev, A.G. Guluzade et al. Kimya Problemleri, 2, 159-164 (2015)

17. V.V. Parshutin, V.G. Revenko et al. Protection Of Metals And Physical Chemistry Of Surfaces, 46(4), 489-495 (2010) 
18. V.V. Parshutin, V.G. Revenko, N.S. Sholtoyan et al. Fizikokhimiya poverkhnosti i zashchita materialov, 46(4), 414-420 (2010)

19. J. Liao, H. Fukui, T. Urakami, H. Morisaki, Corrosion Science, 52(4), 1393 (2010)

20. C. Cote, O. Rosas, R. Basseguy, et al., Bioelectrochemistry, 97, 97-109 (2014)

21. N. Shinoda, T. Shimada, Corrosion Engineering, 60( 11), 399 (2011)

22. Ye.I. Andreyuk, V.I. Bilay, E.Z. Koval, I.A Kozlova. Microbial Corrosion and its Promoters (Naukova Dumka, Kiyev)

23. G.V Karpenko, Steel Strength in the Corrosive Medium, (Mashgiz, Moscow, 1993)

24. M. Shahzad, A.H. Qureshi, H. Waqas, N. Hussain, Materials And Design, 32(10), 5154-5158 (2011)

25. O. A. Ruzhitskaya, Vestnik Irkutskogo gosudarstvennogo tekhnicheskogo universiteta 9 (92), 131-133 (2014)

26. O.A. Ruzhitskaya, Vodosnabzheniye i kanalizatsiya, 5-6, 30-34 (2014)

27. O. A Ruzhitskaya, V. P. Salomeyev, Ye. S. Gogina, Vodosnabzheniye i sanitarnaya tekhnika, 6, 43-47 (2013)

28. Ye. I. Pupyrev, N. V. Zakhvatayeva, A. S. Shelomkov, A. Yu. Kozhushko, Vodosnabzheniye i sanitarnaya tekhnika, 8, 55-59(2009)

29. Degremont. Technical reference for water treatment. (Novyy zhurnal, SPetersburg, 2007)

30. Z. Lu, T. Shoji, F. Meng, et al. Corrosion Science, 53(1), 247-262 (2011)

31. G.F. Lakin, Biometry (Vysshaya shkola, Moscow, 1990) 